\title{
Analysis of the Relationship between Quality of Financial Statements Review and Audit Findings on the Local Government Financial Statements in Daerah Istimewa Yogyakarta Province, Indonesia
}

\author{
DWI WINDARSIH* \\ IRWAN TAUFIQ RITONGA \\ Universitas Gadjah Mada
}

\begin{abstract}
There are two objectives of this study. The first objective is to evaluate the quality of local government financial statement (LGFS) review conducted by five local government inspectorate offices (i.e., internal auditor) in the Province Daerah Istimewa Yogyakarta, Indonesia. Secondly, this study analyzes the relationship between the quality of LGFS review and the number of audit findings conducted by the Supreme Audit Board (i.e., the external auditor). This study uses qualitative methods. Results of this study indicate that the quality of LGFS review varies significantly among local governments as shown by the score of review quality ranging from $73.08 \%$ to $83.59 \%$. Furthermore, the quality of LGFS review has a negative correlation with the number of audit findings, which means that the better the quality of the review the smaller the number of audit findings. Results of this study are expected to provide input to local government inspectorates to take necessary steps so that the implementation of LGFS review to be more qualified. In turn, the number of audit findings can be minimized. Also, the academic benefits of this research are to become a reference for the next researcher who wants to do further research related to the implementation of the LGFS review.
\end{abstract}

Keywords: Financial Statement Review, Audit Finding, Local Government, Supreme Audit Board, Inspectorate.

Intisari: Ada dua tujuan dari penelitian ini. Tujuan pertama adalah untuk mengevaluasi kualitas ulasan laporan keuangan pemerintah daerah(LGFS) yang dilakukan oleh lima kantor inspektorat pemerintah daerah (yaitu auditor internal) di Provinsi Daerah Istimewa Yogyakarta, Indonesia. Kedua, studi ini menganalisis hubungan antara kualitas tinjauan LGFS dan jumlah temuan audit yang dilakukan oleh Badan Pemeriksa Keuangan (yaitu auditor eksternal). Penelitian ini menggunakan metode kualitatif. Hasil penelitian ini menunjukkan bahwa kualitas tinjauan LGFS bervariasi secara signifikan di antara pemerintah daerah seperti yang ditunjukkan oleh skor kualitas ulasan mulai dari 73,08\% menjadi 83,59\%. Selanjutnya, kualitas tinjauan LGFS memiliki korelasi negatif dengan jumlah temuan audit, yang berarti bahwa semakin baik kualitas peninjauan semakin kecil jumlah temuan audit. Hasil penelitian ini diharapkan dapat memberikan masukan kepada inspektorat pemerintah daerah untuk 
mengambil langkah-langkah yang diperlukan sehingga pelaksanaan tinjauan LGFS menjadi lebih berkualitas. Pada gilirannya, jumlah temuan audit dapat diminimalkan. Selain itu, manfaat akademik dari penelitian ini adalah menjadi referensi bagi peneliti berikutnya yang ingin melakukan penelitian lebih lanjut terkait dengan pelaksanaan tinjauan LGFS.

Kata Kunci: Penelaahan Laporan Keuangan, Temuan Audit, Pemerintah Daerah, Badan Pemeriksa Keuangan, Inspektorat.

\section{Introduction}

Local Government Finance Statements (LGFS) has a vital role in local government accountability. Therefore, the central government is attempting to improve regulations governing the financial reporting system of local government. One such regulation is the Minister of Home Affairs Regulation Number 4 of 2008 on the Guidelines for Review on Local Government Finance Statements, which was published on January 17, 2008. The regulation governing the obligations of local government inspectorate office (i.e., internal auditor) to reviews LGFS before the financial statements are audited by the Supreme Audit Board (i.e., external auditor). Purpose of LGFS review is to provide limited assurance that the financial statements have been prepared based on adequate internal control and presented following government accounting standards. Results of LGFS review are submitted to the head of the region as a basis for making a statement of the responsibility of the head of the region. Regional Head must submit the financial report accompanied by a statement of responsibility (President of Indonesia, 2006).

The statement of responsibility states that the financial statements have been prepared based on an adequate internal control system. This indicates that the statement has a meaning of big responsibility for regional heads, particularly in relation to supporting the efforts of local governments in realizing good financial governance. Given the importance of the statement of the responsibility of the regional head, it will require a strong foundation for making the statement. The strong foundation is provided through reviewing the financial statements of local government. The internal auditor of local government reviews the financial statements to provide assurance that the financial 
statements have been prepared based on an adequate internal control system and following government accounting standards. An output of financial statement review is a statement that the inspectorate has reviewed the financial statements. This statement became the basis for regional heads in making a statement of responsibility toward local government financial statements.

To improve the quality of local government financial statements, five local government inspectorate offices (i.e., Regency of Gunung Kidul, Regency of Sleman, Regency of Bantul, Regency of Kulon Progo Regency, and City of Yogyakarta) in Daerah Istimewa Yogyakarta (DIY) has conducted financial statements reviews. However, the conclusion of the audit conducted by the Supreme Audit Board (SAB), the state auditor, indicates significant findings in all regencies and city' financial statements although four local governments obtain unqualified opinions and one local government obtain a qualified opinion. The audit findings are an indication of problems obtained during an audit. The audit findings related to 1) non-compliance with the provisions of the legislation; 2) significant irregularities and impropriety; 3) significant weaknesses of internal control systems; 4) failure of a program being examined; and 5) a mismatch between the factual conditions with the established criteria (The Supreme Audit Board, 2007).

Based on the description above, it is essential to explore how the quality of the LGFS reviews that have been conducted by the local government inspectorates and its relationship with audit findings undertaken by the SAB. Thus, the research objectives are to evaluate the quality of the LGFS review conducted by five local government inspectorates (i.e., internal auditor) in DIY Province and to analyze the relationship between the quality of the LGFS review and the number of audit findings by the SAB (i.e., external auditor).

This study is based on the motivation to contribute ideas related to the implementation of the review of LGFS in Indonesia. This research is expected to provide practical benefits and academic benefits. Practical benefits anticipated by the 
authors are to provide information/feedback to policymakers to take necessary steps so that the implementation of LGFS review by local government inspectorate to be more qualified. Also, the academic benefits of this research are to become a reference for the next researcher who wants to do further research related to the implementation of the LGFS review.

\section{Theoretical Framework and Hypothesis Development}

\subsection{Local Governments in Indonesia and Local Governments in Daerah Istimewa Yogyakarta Province}

The territory of Indonesia is divided into thirty-four provincial territories. Each provincial territory is divided into regency and municipal territories. Each provincial, regency and municipal territory has a local government. The head of a local government heads each region called the regional leader. The regional leader for the province is called the governor, for the district called the regent and for the city is the mayor. The regional head is assisted by one deputy regional head, for the province called the deputy governor, for the district called the vice-regent and for the city is called the deputy mayor.

A provincial territory is an administrative area which becomes the working area for the governor as the representative of the Central Government and also the working area for the governor in carrying out general government affairs in the territory. Regency/municipal territories are administrative areas which become the working area for regents/mayors in organizing general government affairs in regencies/municipalities.

There are 542 autonomy local governments in Indonesia. They are divided into three types of local government, which are thirty-four provincial, local government, ninety-three municipal local government, and 415 district local governments. One of the provinces in Indonesia is the Daerah Istimewa Yogyakarta Province. DIY Province is one of two special areas in Indonesia. The specialty of this Province is related to its 
role in the struggle for the independence of the State of Indonesia. DIY Province consists of one provincial government, one municipal government, and four regencies' governments (Sleman, Bantul, Kulonprogo, and Gunungkidul. DIY Province is one of the provinces with the smallest region in Indonesia. However, DIY Province is one of the best provinces in the aspects of regional financial management as well as human resource development.

\subsection{Local Government Financial Statements Audit in Indonesia}

Local government financial audit is regulated in Law Number 15 the Year 2004 regarding State Audit. Local government financial audits are only conducted by the Supreme Audit Board. The Supreme Audit Board is a free and independent institution, as outlined in Article 23E of the 1945 Constitution.

Local government financial audits include examining local financial management and examining om local financial responsibilities. The Supreme Audit Board conducts an audit on local government financial statements to provide an opinion about the fairness of the information presented in the government financial statements. Opinion is formulated based on four criteria, which are conformity with government accounting standards, adequacy of disclosure, compliance with laws and regulations, and the effectiveness of the internal control system. There are four types of opinions that can be given by the Supreme Audit Board, namely unqualified opinion, qualified opinion, adverse opinion, and disclaimer of opinion.

\subsection{Local Government Financial Statements Review (LGFS Review) in Indonesia}

LGFS review is a procedure to trace numbers, to request information, and to analyze LGFS that must be undertaken on a sufficient basis by the local government inspectorate. The retoview provides limited assurance on the financial statements that there are no material modifications that should be made to the financial statements so that the financial statements presented are based on the adequate internal control system and according to the Government Accounting Standards (Ministry of Home Affairs, 
2008). The objective of the LGFS review is to provide limited assurance that the financial statements have been prepared based on an adequate internal control system and presented follo wing government accounting standards. LGFS review is carried out no later than two months after the fiscal year ends.

In practice, the implementation of the review has similarities with the audit. All technical review is also included in the audit techniques. Adequate confidence in the audit exceeds the limited confidence in the review, which means that some of the audit techniques have been done through review techniques and sufficient confidence in audit has been carried out with limited confidence in the review. LGFS review is done by tracing numbers, requesting information, and analytic procedures. Tracing numbers is starting from the financial statements into evidence/source documents, but not up on proof testing (i.e., physical examination and confirmation). On the other hand, an audit is carried out by tracing numbers up on the testing of evidence.

The LGFS review consists of three main stages: planning, implementation, and reporting. In the planning stage, reviewers have to pay attention to the principle of conformity, alignment, avoiding overlap, efficiency, and effectiveness in utilizing their resources. Planning involves an understanding of the entity, an assessment of the internal control system, and preparation of review working program (Ministry of Home Affairs, 2008).

In the implementation phase, the reviewer performs procedures of review that have been written in the working program of review. Implementation of a review will be the basis of preparing a report of review results. Implementation of review begins with the collection of financial information in the form of audited financial statements in the past year, monthly reports, quarterly, semiannual, annual, accounting policies and any other information required. Implementation of review is documented in the review working paper, which contains review objectives, a list of interview questions and questionnaires, as well as the work step procedure. In implementing the review, several techniques can be done such as tracing numbers, requesting information, and analytic procedures. 
The final stage in the process of an LGFS review is reporting the results of the review. At this stage, reviewers convert results of review working papers which has been supervised into the form of review report. The report of the review results is presented in the form of a letter containing a statement that financial statements have been reviewed and signed by the inspector. Statement of review is to conclude a result of a review in the form of a statement made by the inspectorate. The statement of review can be review statements without explanatory paragraph or review statements with an explanatory paragraph. Report of results of review also contains problems that occur in the preparation and presentation of financial statements, recommendations, and corrections that have been made by local government chief financial officer.

\subsection{Quality of LGFS Review}

Quality is the ability of a product or service to meet customer needs both obvious or hidden (Heizer \& Render, 2005). Quality is a concept that is quite difficult to be understood and agreed upon. In the context of LGFS review, the primary customer of local government including its working units which are the subjects of review.

Characteristics of LGFS review are similar to characteristics of an audit; therefore, authors conducted a literature review regarding the quality of audit to elaborate quality of the review. The concept of audit quality is a complex concept and difficult to measure (DeAngelo, 1981). According to DeAngelo (1981), audit quality is a given probability by an auditor to discover and report on the existence of a breach/fraud in the accounting system of its clients.

Similar to audit quality, review quality is difficult to measure objectively. Therefore, a variety of dimensions are used to determine the quality of the review. In this study, criteria of review quality are adapted from the criteria of audit quality found in Behn et al. (1997). Behn et al. (1997) developed the criteria from the study of Carcello, Hermanson, and McGrath (1992). The criteria include an experience of review team in reviewing local governments financial statement, knowledge of entity being 
reviewed, responsiveness to the needs of clients, technical competence, strong commitment to review quality, and engagement of leader (i.e., the inspector) in the implementation of review. Other criteria are independence and objectivity, cautious, implementation of review following review working program, the involvement of the former review team, adherence to the code of conduct, and skepticism. The following Table 1 shows the elements and indicators of quality of LGFS review. 
Table 1:

Elements and Indicators of Quality of LGFS Review

\begin{tabular}{|c|c|c|}
\hline \multicolumn{2}{|c|}{$\begin{array}{l}\text { Criteria of Quality of Local } \\
\text { Government Financial Statements } \\
\text { Review (adapted from Behn et al., } \\
\text { 1997) }\end{array}$} & Indicators of Quality of Review (adapted from Carcello et al., 1992) \\
\hline 1. & $\begin{array}{l}\text { Experience of the review } \\
\text { team in reviewing the } \\
\text { financial statements of local } \\
\text { government. }\end{array}$ & $\begin{array}{l}\text { a. Coordinator of the review team has experience in conducting the review. } \\
\text { b. Technical controller of the review team has experience in conducting the review. } \\
\text { c. Leader of the review team has experience in conducting the review. } \\
\text { d. The review team members are experienced in conducting the review. }\end{array}$ \\
\hline 2. & $\begin{array}{l}\text { Knowledge of entity being } \\
\text { reviewed }\end{array}$ & $\begin{array}{l}\text { a. Reviewers are gathering information/news related to the entity reviewed. } \\
\text { b. Reviewers read the Review Report of the previous period. } \\
\text { c. Reviewers read financial management policies and/or regulations of regent/mayor regarding the systems and procedures for } \\
\text { financial management. } \\
\text { d. Reviewers read the accounting policies of local government. } \\
\text { e. Reviewers do a question and answer session with the parties directly involved in every transaction process. } \\
\text { f. Reviewers do a question and answer session with the parties involved in the accounting process. }\end{array}$ \\
\hline 3. & $\begin{array}{l}\text { Responsive to the needs of a } \\
\text { client }\end{array}$ & $\begin{array}{l}\text { a. The review team can complete the review at a predefined time. } \\
\text { b. The review team provides advises/recommendations to local government working units related to the presentation of the } \\
\text { financial statements contained in the review report. } \\
\text { c. All recommendations are followed up by local government working units when review report is published. }\end{array}$ \\
\hline 4. & Technical competence & $\begin{array}{l}\text { a. All the members of the review team have been certified as an auditor and/or have a background in accounting education. } \\
\text { b. All review team members have attended training of review of financial statements. }\end{array}$ \\
\hline
\end{tabular}

*Corresponding author: abangupi@yahoo.com 
The Indonesian Journal of Accounting Research - May, Vol. 20, No.2, 2017

\begin{tabular}{|c|c|c|}
\hline 5. & $\begin{array}{l}\text { Has a strong commitment to } \\
\text { the quality of the review }\end{array}$ & $\begin{array}{l}\text { a. Inspectorate carries out in-house training on a regular basis for the reviewer. } \\
\text { b. Inspectorate is responsible for ensuring that the review team members meet continuing education requirements. } \\
\text { c. Inspectorate actively encourages staff for training and examination of government accounting. }\end{array}$ \\
\hline 6. & $\begin{array}{l}\text { Engagement of inspectorate } \\
\text { leader (i.e., the inspector) in } \\
\text { the implementation of review. }\end{array}$ & $\begin{array}{l}\text { a. An inspector visits the review objects (not only the review team members were present at the time of the review) at the time of } \\
\text { the initial meeting (entry briefing) and the final meeting (exit briefing). } \\
\text { b. Inspector (who sign the review task) is actively involved in the planning, process, and signing of the final result. } \\
\text { c. There is frequent communication between the inspector with the head of local government working units. }\end{array}$ \\
\hline 7. & Independence and objective & $\begin{array}{l}\text { a. The review team did not have a financial interest with the entity being reviewed, either directly or indirectly. } \\
\text { b. The review team did not have a cooperative relationship with the entity being reviewed. } \\
\text { c. If there is interference in the independence of the review team that may affect the implementation of review, the reviewer } \\
\text { rejects the review assignment. For example, interruption due to the existence of a consanguinity relationship or have worked } \\
\text { or have provided services to the entity being reviewed. } \\
\text { d. Assessment given by the review team is objective and impartial towards all things related to the implementation and reporting } \\
\text { of the results of the review. }\end{array}$ \\
\hline 8. & Cautious & $\begin{array}{l}\text { a. The review team implements the review based on the regulations, namely the Minister of the Home Affairs Regulation No. } 4 \\
\text { of } 2008 \text {. } \\
\text { b. The review team to document all of the review procedures in the review working papers. }\end{array}$ \\
\hline 9. & $\begin{array}{l}\text { Implementation of review } \\
\text { following the working } \\
\text { program of the review }\end{array}$ & $\begin{array}{l}\text { a. There is a working programme of review. } \\
\text { b. Working programme of review lists steps of review, review techniques, data sources, reviewers, and schedule for review. } \\
\text { c. The review team evaluates systems and procedures of local government financial management. } \\
\text { d. The review team observes and/or interviews the parties related to every existing activity, and then the results are documented } \\
\text { in the assessment table of an internal control system. } \\
\text { e. The review team analyzed the risks that have been identified on the possibility of a material misstatement in the financial } \\
\text { statements. The results of the analysis are documented in the assessment table of the internal control system. }\end{array}$ \\
\hline
\end{tabular}




\begin{tabular}{|l|l|l|}
\hline & & $\begin{array}{l}\text { f. The review team analyzed the risks that have been identified in the direction of the implementation of review. The results of } \\
\text { the analysis are documented in the assessment table of the internal control system. }\end{array}$ \\
\hline 10. & $\begin{array}{l}\text { Involvement of the former } \\
\text { review team }\end{array}$ & $\begin{array}{l}\text { a. There is effective communication between the current review team with the previous review team. } \\
\text { b. The current review team using the previous review working paper as a reference. }\end{array}$ \\
\hline 11. & $\begin{array}{l}\text { Adherence to the code of } \\
\text { ethics }\end{array}$ & $\begin{array}{l}\text { a. The review team looks to have high ethical standards as evidenced by the absence of code violations in the implementation of } \\
\text { review. } \\
\text { b. No complaints concerning violations of the code of ethics by the review team. }\end{array}$ \\
\hline 12. & $\begin{array}{l}\text { Keeping skepticism } \\
\text { a. The review team to have an attitude that includes a questioning mind and evaluatecriticallys the presentation of LGFS critically. } \\
\text { of the leader is undoubted. }\end{array}$ \\
\hline
\end{tabular}




\subsection{Audit Findings}

State auditor (i.e., the Supreme Audit Board) has the authority and responsibility to conduct an audit of state financial management and accountability (the Republic of Indonesia, 2004). In doing the audit, the auditor might find the practice, procedure, or a transaction conducted by the auditee, notwithstanding the provisions of or even deviate from the provisions of law.

The state auditors are obliged to report audit findings in their audit reports. Audit findings are a set and synthesis of data and information collected and processed during the audit conducted on the particular entity; and presented in a systematic and analytic includes elements, conditions, criteria, cause, and effect.

Elements are parties involved in audit findings, while condition illustrates a problem occurs. The criteria are rules, laws, and guidelines used to perform the evaluation. The cause is everything that makes the difference between the conditions and the criteria, while size or magnitude of the consequences that have occurred or will occur because of the difference between the conditions and the criteria is called effect. Based on audit findings disclosed, auditor provides recommendations to auditee to overcome the problems arise. Effective recommendations will eliminate the causes of audit findings.

\section{Research Method}

\subsection{Research Design}

This study utilizes a qualitative method because little research has been done on phenomenon needs to be explored and understood (i.e., LGFS review). Furthermore, Creswell (2013) states that qualitative research is especially useful when the researcher does not know the essential variables to examine. This type of approach may be needed because the topic, i.e.LGFS review, is new; and the subject has never been addressed with a specific sample or group of people (Creswell, 2013).

\subsection{Types and Source of Data}

Data used in this study consisted of primary data and secondary data. Primary data was collected directly through interviews to the member of review team who reviewed local government financial statements in the fiscal year 2013. Secondary data were collected from the archives and documents such as a letter of assignment review, review of working program, review working papers, review reports, audit reports from the state auditor, strategic planning documents, and other data related to the duties and functions of the inspectorate. 


\subsection{Data Collection Technique}

The collection of data is carried out through field research and library research. The field research is carried out by visiting objects of research directly, namely Sleman, Bantul, Kulon Progo District Inspectorate Offices, and the City of Yogyakarta. The method used to collect data in the field research is documentation and interviews.

The research literature is done by reading and understanding all matters related to the problems studied, either from books, previous studies, related regulations, articles that discuss LGFS review, and audit reports produced by the Supreme Audit Board. Interviews in this study are aimed to obtain qualitative data to answer questions about how the quality of the LGFS reviews. Face-to-face in-depth interviews were conducted with parties who perform local government financial statements reviews. The questions asked to refer to the criteria developed by the researchers as provided in Table 1 above.

Interviews were conducted with four reviewers at each local government inspectorate office. The four persons are a reviewer coordinator, a reviewer controller, a team leader of the review team, and a member of the review team. Thus, the total numbers of parties interviewed were 20 persons. The duration of the interview varied between 30 to 60 minutes for each respondent. The interview script is available upon request to the correspondent author via email.

\subsection{Data Analysis Techniques}

The data analysis involves the collection of open data, which is based on more general questions; and analysis of information from the participants (Creswell, 2013). Data analysis was performed by analyzing data from interviews and documents related to the implementation of LGFS review by local government inspectorates.

The data analysis method used in this research is data reduction, categorization, synthesis, and conclusion. Reduction or simplification of data is done with re-examine all the interviews and documents related to the implementation of LGFS review by the inspectorates. Researchers conduct the process of data reduction at the time of typing the transcript of the interview. Categorization is the process of collecting information that is organized by category required. Main points were obtained from interviews are arranged systematically to obtain similarity of theme and meaning. Data synthesis is an attempt to associate one category to another category. Each sentence or quote with the same categories is pooled as one group. Results of data synthesis then analyzed and described to conclude.

Qualitative data analysis is done by looking at the fit between practices/facts that occurred in the field with the criteria established for determining the quality of the review. The results of the comparison between the facts and criteria then measured through the provision of figures to obtain a numerical description of levels of review quality. According to Hartono (2010), provision of numerical description could be in the form of the continuum (range) or specific figures. 
Measuring quality of the review refers to indicators that have been set

In doing the scoring, researchers gave a score of 1 for each indicator following the facts that occurred in the field and a score of 0 for each indicator not at all following defined criteria. The scoring results are then calculated as a percentage resulting in a figure that shows the quality level of LGFS review. The formula used is as follows:

\section{The quality level of LGFS review $=\frac{\text { Total score obtained }}{\text { Maximum Score }} \times 100 \%$}

To deepen the analysis found in the previous step, this research also performs further analysis by analyzing the relationship between qualities of LGFS review and number of audit findings. To test the relationship, this study utilizes non-parametric statistics with Spearman correlation test. The use of nonparametric statistics because this study only uses small data, which are five local government inspectorates.

\section{Results}

\subsection{Evaluation of the Quality of LGFS Review}

After collecting primary data by interviewing 20-person reviewers in five inspectorate offices, then authors conduct the following steps: data reduction, categorization, synthesis, and conclusion. The data is available upon request to the correspondent author.

Evaluation of the quality of LGFS review is done by assessing the degree of correspondence between the implementation of the review toward the criteria of quality of the review. The more criteria met then, the better the quality of the review. Based on interviews, the researchers compared the fit between practices/facts that occurred in the field with the criteria established to determine the quality of LGFS review. The result of the comparison between facts and criteria is then measured by giving a score. In doing the scoring, researchers gave a maximum score of 1 for each item indicator criteria following the facts that occurred in the field and a minimum score of 0 for each indicator criteria that did not fit the criteria set. Then, all the scores were added up, and the result is divided by the maximum score that can be achieved. The result is in the form of a percentage. The result of this percentage indicates the quality level of the LGFS review conducted by the inspectorate.

Results of the evaluation of the quality level of LGFS review are as follows (from the highest score to the lowest score): Regency of Sleman 82.56\%, City of Yogyakarta $81.28 \%$, Regency of Kulon Progo 80.00\%, Regency of Bantul 76.15\%, and Regency of Gunungkidul $73.08 \%$. Regency of Sleman has a score of $82.56 \%$ means that the review conducted by the inspectorate meet $82.56 \%$ of the criteria set. Results of the evaluation of five local governments 
above show a significant variation of review quality among the local governments. Details of the scores for each criterion can be seen in Table 2 below. 
Table 2

Results of Evaluation on Quality of Review

\begin{tabular}{|c|c|c|c|c|c|c|}
\hline \multicolumn{7}{|c|}{ 1. Results of Evaluation on the Review Team Experience } \\
\hline \multirow[b]{2}{*}{ No } & \multirow[b]{2}{*}{ Indicators of Quality of Review } & \multicolumn{5}{|c|}{ Score of Evaluation } \\
\hline & & Sleman & $\begin{array}{l}\text { Kulon } \\
\text { Progo }\end{array}$ & $\begin{array}{c}\text { Gunung } \\
\text { Kidul }\end{array}$ & Bantul & $\begin{array}{c}\text { Yogyaka } \\
\text { rta }\end{array}$ \\
\hline 1) & Coordinator of the review team has experience in conducting the review. & 1.0 & 0.0 & 1.0 & 1.0 & 1.0 \\
\hline 2) & Technical controller of the review team has experience in conducting the review. & 0.8 & 1.0 & 1 & 1.0 & 1.0 \\
\hline 3) & Leader of the review team has experience in conducting the review. & 1.0 & 1.0 & 1.0 & 1.0 & 1.0 \\
\hline 4) & The review team members are experienced in conducting the review. & 1.0 & 1.0 & 1.0 & 0.6 & 1.0 \\
\hline \multicolumn{2}{|r|}{ Total Score } & 3.8 & 3.0 & 4.0 & 3.6 & 4.0 \\
\hline \multicolumn{7}{|c|}{ 2. Results of evaluation on knowledge of Entity Being Reviewed } \\
\hline 1) & Reviewers are gathering information/news related to the entity reviewed. & 1.0 & 1.0 & 1.0 & 1.0 & 1.0 \\
\hline 2) & Reviewers read the Review Report of the previous period. & 1.0 & 1.0 & 1.0 & 1.0 & 1.0 \\
\hline 3) & $\begin{array}{l}\text { Reviewers read financial management policies and/or regulations of regent/ mayor about the systems and } \\
\text { procedures for financial management. }\end{array}$ & 1.0 & 1.0 & 1.0 & 1.0 & 1.0 \\
\hline 4) & Reviewers read the accounting policies of local governments. & 1.0 & 1.0 & 1.0 & 1.0 & 1.0 \\
\hline 5) & Reviewers do a question and answer session with the parties directly involved in every transaction process. & 0.5 & 0.0 & 0.0 & 0.0 & 0.5 \\
\hline 6) & Reviewers do a question and answer session with the parties involved in the accounting process. & 0.5 & 0.5 & 0.5 & 0.5 & 0.5 \\
\hline & Total Score & 5.0 & 4.5 & 4.5 & 4.5 & 5.0 \\
\hline \multicolumn{7}{|c|}{ 3. Results of evaluation on responsive to the needs of the client } \\
\hline 1) & The review team can complete the review at a predefined time. & 1.0 & 1.0 & 1.0 & 1.0 & 1.0 \\
\hline 2) & $\begin{array}{l}\text { The review team provides advises/recommendations to local government working units related to the } \\
\text { presentation of the financial statements contained in the review report. }\end{array}$ & 1.0 & 1.0 & 0.5 & 1.0 & 1.0 \\
\hline
\end{tabular}




\begin{tabular}{|c|c|c|c|c|c|c|}
\hline 3) & $\begin{array}{l}\text { All recommendations have been followed up by local government working units when the review report is } \\
\text { published. }\end{array}$ & 0.9 & 1.0 & 1.0 & 0.8 & 1.0 \\
\hline & Total Score & 2.9 & 3.0 & 2.5 & 2.8 & 3.0 \\
\hline \multicolumn{7}{|c|}{ 4. Results of Evaluation on technical competence } \\
\hline 1) & $\begin{array}{l}\text { All the members of the review team have been certified as an auditor and/or have a background in } \\
\text { accounting education. }\end{array}$ & 1.0 & 1.0 & 0.8 & 1.0 & 0.9 \\
\hline 2) & All review team members have attended training of review of financial statements. & 1.0 & 1.0 & 1.0 & 1.0 & 1.0 \\
\hline & Total Score & 2.0 & 2.0 & 1.8 & 2.0 & 1.9 \\
\hline \multicolumn{7}{|c|}{ 5. Results of Evaluation on a strong commitment to the quality of the review. } \\
\hline 1) & Inspectorate carries out in-house training on a regular basis for the reviewer. & 1.0 & 0.3 & 0.2 & 1.0 & 0.5 \\
\hline 2) & $\begin{array}{l}\text { Inspectorate is responsible for ensuring that the review team members meet continuing education } \\
\text { requirements. }\end{array}$ & 1.0 & 1.0 & 1.0 & 1.0 & 1.0 \\
\hline 3) & Inspectorate actively encourages staff for training and examination of government accounting. & 1.0 & 1.0 & 1.0 & 1.0 & 1.0 \\
\hline & Total Score & 3.0 & 2.3 & 2.2 & 3.0 & 2.5 \\
\hline \multicolumn{7}{|c|}{ 6. Results of Evaluation on the engagement of inspectorate leader (i.e., the inspector) in the implementation of review. } \\
\hline 1) & $\begin{array}{l}\text { An inspector visits the review objects (not only the review team members were present at the time of the } \\
\text { review) at the time of the initial meeting (entry briefing) and the final meeting (exit briefing). }\end{array}$ & 1.0 & 1.0 & 1.0 & 0.5 & 1.0 \\
\hline 2) & $\begin{array}{l}\text { Inspector (who sign the review task) is actively involved in planning. process. and signing of the final } \\
\text { result. }\end{array}$ & 1.0 & 1.0 & 0.7 & 1.0 & 1.0 \\
\hline 3) & There is frequent communication between the inspector with the head of local government working units. & 1.0 & 1.0 & 1.0 & 1.0 & 1.0 \\
\hline & Total Score & 3.0 & 3.0 & 2.7 & 2.5 & 3.0 \\
\hline \multicolumn{7}{|c|}{ 7. Results of Evaluation on independence and objective } \\
\hline 1) & The review team did not have a financial interest with the entity being reviewed. either directly or indirectly. & 1.0 & 1.0 & 1.0 & 1.0 & 1.0 \\
\hline 2) & The review team did not have a cooperative relationship with the entity being reviewed. & 1.0 & 1.0 & 1.0 & 1.0 & 1.0 \\
\hline
\end{tabular}




\begin{tabular}{|c|c|c|c|c|c|c|}
\hline 3) & $\begin{array}{l}\text { If there is interference in the independence of the review team that may affect the implementation of review. } \\
\text { the reviewer rejects the review assignment. For example interruption due to the existence of a consanguinity } \\
\text { relationship or have worked or have provided services to the entity being reviewed. }\end{array}$ & 1.0 & 1.0 & 1.0 & 1.0 & 1.0 \\
\hline 4) & $\begin{array}{l}\text { Assessment given by the review team is objective and impartial towards all things related to the } \\
\text { implementation and reporting of the results of the review. }\end{array}$ & 1.0 & 0.5 & 0.5 & 1.0 & 1.0 \\
\hline & Total Score & 4.0 & 3.5 & 3.5 & 4.0 & 4.0 \\
\hline \multicolumn{7}{|c|}{ 8. Results of Evaluation on Cautious } \\
\hline 1) & $\begin{array}{l}\text { The review team implements the review based on the regulations. namely the Minister of the Home Affairs } \\
\text { Regulation No. } 4 \text { of } 2008 .\end{array}$ & 1.0 & 1.0 & 1.0 & 1.0 & 1.0 \\
\hline 2) & The review team to document all of the review procedures in the review working papers. & 0.3 & 0.3 & 0.3 & 0.3 & 0.3 \\
\hline & Total Score & 1.3 & 1.3 & 1.3 & 1.3 & 1.3 \\
\hline \multicolumn{7}{|c|}{ 9. Results of evaluation on the implementation of review following the working program of the review. } \\
\hline 1) & There is a working programme of review. & 1.0 & 1.0 & 0.0 & 0.0 & 0.0 \\
\hline 2) & $\begin{array}{l}\text { Working programme of review lists steps of review, review techniques, data sources, reviewers, and } \\
\text { schedule for review. }\end{array}$ & 0.6 & 0.6 & 0.0 & 0.0 & 0.0 \\
\hline 3) & The review team evaluates systems and procedures of local government financial management. & 0.0 & 1.0 & 0.0 & 0.0 & 1.0 \\
\hline 4) & $\begin{array}{l}\text { The review team observes and/or interviews the parties related to every existing activity, and then the results } \\
\text { are documented in the assessment table of an internal control system. }\end{array}$ & 0.0 & 0.0 & 0.0 & 0.0 & 0.0 \\
\hline 5) & $\begin{array}{l}\text { The review team analyzed the risks that have been identified on the possibility of a material misstatement } \\
\text { in the financial statements. The results of the analysis are documented in the assessment table of an internal } \\
\text { control system. }\end{array}$ & 0.0 & 0.0 & 0.0 & 0.0 & 0.0 \\
\hline
\end{tabular}




\begin{tabular}{|c|c|c|c|c|c|c|}
\hline 6) & $\begin{array}{l}\text { The review team analyzed the risks that have been identified in the direction of the implementation of } \\
\text { review. The results of the analysis are documented in the assessment table of an internal control system. }\end{array}$ & 0.0 & 0.0 & 0.0 & 0.0 & 0.0 \\
\hline & Total Score & 1.6 & 2.6 & 0.0 & 0.0 & 1.0 \\
\hline \multicolumn{7}{|c|}{ 10. Results of Evaluation on Involvement of Former Review Team } \\
\hline 1) & There is effective communication between the current review team with the former review team. & 1.0 & 1.0 & 1.0 & 1.0 & 1.0 \\
\hline 2) & The current review team using the previous review working paper as a reference. & 1.0 & 1.0 & 1.0 & 1.0 & 1.0 \\
\hline & Total Score & 2.0 & 2.0 & 2.0 & 2.0 & 2.0 \\
\hline \multicolumn{7}{|c|}{ 11. Results of Evaluation on Adherence to the code of ethics } \\
\hline 1) & $\begin{array}{l}\text { The review team looks to have high ethical standards as evidenced by the absence of code violations in the } \\
\text { implementation of review. }\end{array}$ & 1.0 & 1.0 & 1.0 & 1.0 & 1.0 \\
\hline 2) & No complaints concerning violations of the code of ethics by the review team. & 1.0 & 1.0 & 1.0 & 1.0 & 1.0 \\
\hline & Total Score & 2.0 & 2.0 & 2.0 & 2.0 & 2.0 \\
\hline \multicolumn{7}{|c|}{ 12. Results of Evaluation on Keeping skepticism of reviewer } \\
\hline 1) & $\begin{array}{l}\text { The review team to have an attitude that includes a questioning mind and evaluatecriticallys the presentation } \\
\text { of LGFS critically. }\end{array}$ & 1.0 & 1.0 & 1.0 & 1.0 & 1.0 \\
\hline 2) & $\begin{array}{l}\text { The review team does not consider that the leader of an entity being reviewed is dishonest but also does } \\
\text { not think that honesty of the leader is undoubted. }\end{array}$ & 1.0 & 1.0 & 1.0 & 1.0 & 1.0 \\
\hline \multicolumn{2}{|r|}{ Total Score } & 2.0 & 2.0 & 2.0 & 2.0 & 2.0 \\
\hline
\end{tabular}


Of the twelve elements of quality of the review, there are three elements (involvement of former review team, adherence to the code of ethics, keeping skepticism of reviewer) that can be completely satisfied by all inspectorates. On the other hand, two elements with the lowest quality are an element of "implementation of review following the review working program" with a score of $17.33 \%$; and the element of cautious with a score of $65 \%$.

The low score of the element "implementation of review following the review working program" is caused by the absence of review working programme. Only two inspectorates that equipped their review with the review working programme, which are Regency of Sleman and Regency of Kulonprogo. Other factors that contribute to such a low score are the absence of risk assessment and documentation of implementation of review.

\subsection{Audit Findings on Local Government Financial Statements for the Fiscal Year 2013}

The state auditors have audited the financial statements of all local governments in the province Daerah Istimewa Yogyakarta for the fiscal year 2013. In the audit report, the auditors stated their audit findings related to internal control systems and compliance with laws and regulations in each local government. Authors calculate some audit findings from the audit reports. Some audit findings of Regency of Sleman were ten findings; Regency of Kulon Progo was 18 findings. Regency of Gunungkidul was 22 findings. Regency of Bantul was 24 findings and City of Yogyakarta was 16 findings. Those figures show a significant variation of audit findings among the local governments.

\subsection{Assessing the Relationship of Quality of Review and Number of Audit Findings}

Data on quality of review and number of audit findings discussed above were analyzed using the Spearman correlation test. The results are shown in Table 3 below. The correlation coefficient between the quality of the review and the number of audit findings are significant at -0.900 which means that there is a negative correlation between the quality of review and the number of audit findings. The magnitude of the correlation coefficient is approaching -1 indicates that there is an almost perfect correlation between the quality of the review and the number of audit findings. Thus, it can be concluded that a better quality of review could reduce the number of audit findings. 
Table 3

Results of Spearman Correlation Test of Review Quality and Number of Audit Findings

\begin{tabular}{|c|c|c|c|c|}
\hline & & & $\begin{array}{l}\text { Review } \\
\text { Quality }\end{array}$ & $\begin{array}{l}\text { Number of Audit } \\
\text { Findings }\end{array}$ \\
\hline \multirow[t]{6}{*}{$\begin{array}{l}\text { Spearman's } \\
\text { rho }\end{array}$} & \multirow[t]{3}{*}{ Review Quality } & $\begin{array}{l}\text { Correlation } \\
\text { Coefficient } \\
\end{array}$ & 1.000 & $-.900^{*}$ \\
\hline & & Sig. (1-tailed) & & .019 \\
\hline & & $\mathrm{N}$ & 5 & 5 \\
\hline & \multirow[t]{3}{*}{$\begin{array}{l}\text { Number of Audit } \\
\text { Findings }\end{array}$} & $\begin{array}{l}\text { Correlation } \\
\text { Coefficient }\end{array}$ & $-.900^{*}$ & 1.000 \\
\hline & & Sig. (1-tailed) & .019 & \\
\hline & & $\mathrm{N}$ & 5 & 5 \\
\hline
\end{tabular}

*. Correlation is significant at the 0.05 level (1-tailed).

\section{Conclusions, Implications and Limitations}

This study evaluates the quality of LGFS review conducted by five local government inspectorates (i.e., internal auditor) in Daerah Istimewa Yogyakarta Province, and examines the relationship between quality of LGFS review and audit findings found by state auditor (i.e., external auditor). These results indicate that the quality of the LGFS review varies significantly as shown by the value ranging from $73.08 \%$ to $82.56 \%$. The results of the evaluation of review quality are then linked to the phenomenon which there are still many audit findings, both in the number and amount, in five local governments in Daerah Istimewa Yogyakarta Province. Based on the Spearman correlation test, the amount of the coefficient is -0.900 which indicates that there is an almost perfect negative correlation between the quality of LGFS review and the number of audit findings.

These findings confirm the objective of LGFS review as stated in the Minister of Home Affairs Regulation number 4-year 2008, which are (1) to provide adequate assurance that the financial statements have been prepared based on an adequate internal control system and (2) presented in accordance with government accounting standards, instead of for a consolidating report. Therefore, it can be concluded that if the quality of LGFS review is good so that it could identify the weaknesses (if any) of the internal control system and practices that deviate of accounting standards.

Also, those findings also strengthen the relationship between the quality of LGFS review and auditor opinion on LGFS. Gunungkidul Regency with a qualified opinion on its LGFS has the lowest quality of LGFS review. 


\subsection{Research Contribution}

This research is expected to provide practical benefits and academic benefits. Practical benefits expected by the authors are to provide information/feedback to policymakers to take necessary steps so that the implementation of LGFS review by local government inspectorate to be more qualified. Based on the research results, local government inspectorates must improve the element of "results of evaluation on the implementation of review following the working program of the review" in LGFS review immediately. This is the weakest element. In more details, local government inspectorates must fulfill some indicators so that the quality of the LGFS review could increase significantly. Those indicators are working programme of review; working programme of review lists steps of review, review techniques, data sources, reviewers, and schedule for review; review team evaluates systems and procedures of local government financial management; review team observes and/or interviews the parties related to every existing activity, and then the results are documented in the assessment table of the internal control system. Other indicators are review team analyzed the risks that have been identified on the possibility of a material misstatement in the financial statements, and review team performed an analysis of the risks that have been identified on the direction of the implementation of review. Also, the academic benefits of this research are to become a reference for the next researcher who wants to do further research related to the implementation of the LGFS review.

\subsection{Limitation and Suggestion for Future Research}

Limitations of this study are the number of samples that only five local government inspectorate offices in one province. The small number of samples may interfere with the level of generalization of conclusions made. Therefore, future research should increase the number of local government samples from various provinces so that findings can be more generalized.

\section{References}

Behn. B.K., Carcello. J.V., Hermanson. D.R., \& Hermanson. R.H, 1997, The Determinants of Audit Client Satisfaction Among Clients of Big 6 Firms, Accounting Horizons, 11 (1): 7-24.

Carcello, J.V., Hermanson, R.H. and McGrath, N.T., 1992. Audit Quality Attributes: The Perceptions of Audit Partners, Preparers, and Financial Statement Users. Auditing, 11(1), p.1.

Creswell, J.W., 2013, Research Design: Qualitative, Quantitative, and Mixed Methods Approaches, $4{ }^{\mathrm{nd}}$ Edition. Sage Publications.

DeAngelo. L.E. 1981. Auditor Size and Audit Quality. Journal of Accounting and Economics, Vol. 3. No.3. pp. 183-99

Hartono, J, 2010, Metodologi Penelitian Bisnis, BPFE, Yogyakarta.

Heizer. J. \& Render. B. 2005. Operation Management Flexible Version. New Jersey: Pearson Prentice Hall.

Minister of Home Affairs, Minister of Home Affairs Regulation Number 4 the Year 2008 on the Guidelines for Review on Local Government Finance Statements 
President of Indonesia, Government Regulation Number 8 the Year 2006 on Financial Reporting and Government Institutions Performance

The Republic of Indonesia, Act Number 17 the Year 2003 on State Finance

Supreme Audit Board, Regulation Number 1 the Year 2007 on Audit Standard of State Finance 
The Indonesian Journal of Accounting Research - May, Vol. 20, No.2 , 2017

Intentionally Blank 